recorded in southern Britain. The excavations were described before the Society of Antiquaries of London by Sir Cyril Fox on March 31. The Simondston Cairn is of the normal highland Early Bronze Age type and contains burials of two adults and a child, dating from about 1600 B.c. In the southerm rim of the caim were five cremation burials of about a generation later. It was in one of these that the traces of coal were identified. The nearest outcrop of coal is about a mile and a half away. The second cairn, Pond Cairn, lies half a mile away from Simondston and is on a lower level. It is of a very unusual type both as regards its structure and the ritual acts involved in the construction. Near the centre was a rock-cut pit, probably dedicatory, which was filled with stones and contained the scattered burnt bones of a child. The primary burial was an urn of about 1300 B.c. which was covered with a heap of stones and a vertical-sided turf stack. A basin with a projection, phallic in plan, and lined with charcoal, fronted the urn. Around the turf stack was a continuous cairn ring, sixty feet in diameter, with an inner wall face and outer kerb. The space between the ring and the stack was scattered over with charcoal, and had been trodden hard, presumably in some ceremonial movement. Later the inner face of the ring was broken and the pit, to which reference is made above, was dug. It was covered with a pile of stones, linking the ring with the stack. The Pond Cairn is comparable with examples in Devon. With the secondary deposits at Simondston it probably represents an intrusion across the Severn Sea into the Glamorgan plain.

\section{Roman Dorchester}

REsumed excavation on behalf of the Dorset Archæological Society on the site at Colliton Park, Dorchester, which has been purchased by the County Council for the erection of a shire hall, has already produced several discoveries (The Tïmes, March 3). It will be remembered that last year, when excavation began, a large Roman town house was discovered belonging to the Roman city of Durnovaria which underlies the modern town. This has been completely excavated and is to be preserved intact by the County Council. Trial trenches have now revealed that four important Roman buildings underlie the area upon which the shire hall is to be erected. These it is hoped to examine. A well-made path of cobble flints leading to the door of the house has been brought to light. It overlies an earlier wooden cookhouse, furnished with an oven. A large pit was also found. This was circular in plan and lined with blocks of stone. It is fourteen feet in diameter and sixteen feet deep. A passage to the west leads to the Roman town wall. Excavations will be continued for a further period of at least three months.

\section{Jungfraujoch Research Party}

At the end of this month Mr. G. Seligman, author of "Snow Structure and Ski Fields", will take a party of scientific workers to the Jungfraujoch Research Institute in Switzerland to undertake scientific research work on glaciers. This will be the first British expedition ever to spend its whole time studying glaciological problems, and it will form a continuation of Mr. Seligman's previous researches on the nature of snow. The party will spend five months at the Institute, at a height of more than 11,000 feet, and will consist of : Mr. T. P. Hughes, of the Physical-Chemical Laboratory, Cambridgephysicist; Mr. M. F. Perutz, of the Crystallographic Laboratory, Cambridge-crystallographer; Mr. A. E. Benfield, of the Department of Geodesy and Geophysics, Cambridge, and Mr. E. A. Ferguson, of the Department of Geography, Cambridge-assistants. The chief problem to be investigated will be the transition of firn into glacier ice, but other problems, particularly those which may have some bearing on the main question, will be investigated, notably the movement of glaciers, the formation of ice-bands and the connexion, if any, between those in the névé regions and those near the snout of the glacier. In addition, Mr. Hughes will carry out certain experiments on the friction of solid bodies on ice, in connexion with his work at the Physical-Chemical Laboratory, Cambridge. Mr. Seligman has been granted a Leverhulme Research Fellowship for the purpose of this research, and the expedition is also supported by the Royal Geographical Society, the Ski Club of Great Britain and the Alpine Ski Club.

\section{Changing Conceptions of Education}

Aт a public meeting of the Derbyshire County Association of the National Union of Teachers on March 26, Mr. A. E. Henshall, education secretary of the Union, spoke on present-day teachers' aims and attitudes as contrasted with those of their predecessors. The attitudes established by the notorious payment-by-results system persisted long after its abolition, but to-day there is fairly general acceptance of the view that the teacher is concerned before everything else with the welfare of the individual child, considered as a person destined in due course to contribute to the welfare of the community as a citizen of a democratic State. It follows, at least in theory, that teachers of children in all stages in every kind of school-infants, junior, senior, central, secondary-are united in a single task and owe it to themselves and their charges that they should cooperate as fellow workers in a unitary service. To promote such co-operation by providing convenient occasions for getting together and comparing notes is an important function of the local associations of the National Union. Mr. Henshall stressed the pioneer role of the new senior schools and warned their teachers against sacrificing their comparative freedom in a misguided effort to rival the secondary schools. With equal emphasis he insisted on the importance of the junior schools, the teachers of which should be regarded as having a status not inferior to that of senior school teachers.

\section{Social Services of the League of Nations}

IN an article entitled "The Non-Political Value of the League" contributed to the Quarterly Review for 
January, Capt. A. L. Kennedy gives an admirable survey of the services rendered by the League of Nations technical organizations in non-political fields. He stresses the value of the resettlement of populations in Greece under the League Commission as a contribution to European peace and indicates the need for dealing with questions of refugees and minorities which still persists. In regard to opium, the co-operation established at Geneva has resulted in a central office which maintains supervision over a complete branch of economic activity, from the import of the raw material to the consumption of the manufactured article and in checking its trans. port from one country to another. This achievement has, however, set the League the even harder task of suppressing the illegitimate traffic which still flourishes to a serious extent and also the task of controlling the raw material. Again, the League has provided a central body for collating and directing measures against the traffic in women and children, and it has every claim to be regarded as the world's ministry of health, not only co-ordinating health work in different countries, as well as research and standardization but also, as in the Singapore Epidemiological Intelligence Bureau, providing an intelligence service for the prevention of epidemics. Capt. Kennedy writes appreciatively of services rendered to China before the onslaught of Japan occurred as well as to the reconstruction work in Austria, the work of the Mandates Commission and of the International Labour Office and the Permanent Court of International Justice. This well-balanced assembly of facts leaves no room for doubt that if the failure to use the League in the political sphere led to its abandonment, we should require an exactly similar organization to carry on its present non-political activities if both nations and individuals are not to be deprived of services which have given and are giving them relief from want and suffering, higher moral and material standards and opportunities of a useful life.

\section{Scientific Research in New Zealand}

THE eleventh annual report of the Department of Scientific and Industrial Research, New Zealand, covers the year 1936-37, and, in addition to the secretary's report and the reports of the research committees of the Council, includes the reports of the Dominion Laboratory, the Geological Survey Branch, the Meteorological Branch and the Dominion, Apia and Magnetic Observatories. The Minister's covering statement refers to the establishment of a Bureau of Social Science Research, the work of which will include the co-ordination of the activities of research bodies or individuals in this field and the undertaking of investigations to assist the Govern. ment by providing the factual bases for social policy measures. Outstanding developments of the year were the reorganization of plant research under the Plant Research Bureau and the steps taken to establish an Animal Research Bureau. The Plant Diseases Division of the former Bureau has made good progress in the study of virus diseases of farm crops, par- ticularly tobacco, and has also completed comparative trials of new organic mercury dusts. Diseases of tomatoes and potatoes, etc., have also been investigated, and the Entomological Division of the Bureau has obtained satisfactory results in the biological control of the white butterfly, although new lines of attack for the control of the diamond black moth have been necessary. The Dairy Research Institute has made further progress in its study of the control of gas-producing organisms which cause openness in cheese, and has continued its studies of the elimination of the feed taint in butter and cream from certain districts.

THE Wheat Research Institute has continued to expand its long-range work on wheat breeding, while the Leather Research Laboratory has given special attention to methods of assessing the quality of leather as a guide to improvements. A particular group of chemical constituents has been studied in relation to the wearing-value of leather. An extensive programme of fruit research has included an attack on the problem of the mouldy core of apples and the control of internal cork of apples, while the soil and land utilization survey has been continued to give a fairly complete picture of the agricultural resources of the Hawke's Bay province. Other features of the year have been the establishment of the Standards Institute, which has already done much to promote the adoption of standards and establish committees and sub-committees covering a wide range of subjects. Evidence is already available of the benefits of this work to the Dominion. Research associations have been developed during the year in connexion with the tobacco, wool manufacturing and footwear manufacturing industries, and a feature of staff appointments during the year has been the recruitment of New Zealand science graduates who had migrated overseas. Of the total expenditure of $£ 131,957$ of the Department, $£ 71,233$ is on research investigations, $£ 13,268$ of which is derived from industries and £13,243 from sales and miscellaneous recoveries. Expenditure on the Dominion Laboratory was $£ 17,261$ and on the Meteorological Office $£ 12,069$.

\section{The Ontario Research Foundation}

THE report of the Ontario Research Foundation for 1936 refers to the increased work carried out for industry. Two new laboratories for research on paints and on air-conditioning are now running smoothly. In the former, investigations on weathering tests and chemical analysis of white house paints, weathering of structural metal paints, etc., are in progress, while the latter is investigating the 'summer' comfort requirements in regard to temperature and humidity of people in Toronto. The work of the Textiles Division has been concerned with the development of a textile oil for use in processing woollen materials as well as with the development of a process for highresistance tusser silk for electrical insulation purposes, and with processes for the reduction of shrinkage in textile materials. The Division of Engineering and Metallurgy has continued its studies 